New Zealand journal of industrial relations, 1987, 12, 123-126

\title{
Communicating by employee reports: a survey of employee attitudes
}

\author{
Andrew M C Smith* and Michael A Firth+
}

\section{Introduction}

Over the past few years there has been a growing interest in the general disclosure of a company's financial information to all of its employees. In many cases this has manifested itself in the form of a firm issuing what is known as an employee report to its staff. Typically, an employee report summarises the factual information contained in the statutory annual report. but does so in a simplified form which is easier for non-accountants to understand. In addition, the employee report often contains non-financial information which does not appear in the annual accounts nor in any other company publication. While union negotiators may have access to detailed accounting information, the general rank and file employees probably get most of their financial knowledge about the enterprise they work for via an employee report.

A recent study by Firth and Smith (1984) found that nearly one-half of publicly listed New Zealand companies currently produce some form of employee report. Additionally, many of the New Zealand subsidiaries of larger overseas firms also issue such reports. In spite of the large number of firms involved, there has not, until now, been any formal assessment of employee attitudes regarding such reports. The purpose of the paper is to address this need by reporting the results of a questionnaire-based survey of employee opinions.

\section{The survey}

Three companies who were representative of those firms issuing employee reports were approached for permission to survey their employees. The profiles of the companies are as follows:

Company A - A major listed industrial company in the food/tobacco/liquor sector, employing approximately 7500 persons in locations all over New Zealand.

Company B - A major listed industrial company in the engineering/automotive sectors. The group employs approximately 2600 persons in locations all over New Zealand.

Company C - A non-listed co-operative company in the service sector. This company had a high proportion of technical/professional skilled employees. The firm employs approximately 1500 people.

In each case, special efforts were made to ensure the sample of employees selected was reasonably representative of each company's total workforce. Within each firm the responses were analysed across 5 age groups (16-20 years, 21-30, 31-40, 41-50, 50+) and across 4 job categories (management, skilled, unskilled, administrative).

* Lecturer in Accountancy, Victoria University of Wellington

$+\quad$ Professor of Accountancy, University of Colorado at Denver. USA

The authors would like to thank David Smith for his helpful comments. 
Table 1: Employees' ranking of relative importance of employee report disclosures

\begin{tabular}{|c|c|c|c|c|c|c|c|}
\hline & $\begin{array}{c}\text { Not } \\
\text { Important }\end{array}$ & Important & Important & $\begin{array}{l}\text { Highy } \\
\text { Important }\end{array}$ & Important & Average & Kann \\
\hline (a) Summary Profit \& Loss Account ${ }^{* *}$ & $6 \%$ & $11 \%$ & $27 \%$ & $33 \%$ & $13 \%$ & 3.56 & 8 \\
\hline (b) Summary Balance Sheet & 5 & 18 & 32 & 28 & 17 & 3.34 & 12 \\
\hline (c) Summary Funds Statement & 4 & 16 & 38 & 22 & 20 & 3.42 & 10 \\
\hline (d) Value Added Statement & 10 & 22 & 40 & 21 & 7 & 2.93 & 17 \\
\hline (e) Chairman's/Manager's Report & 6 & 14 & 28 & 35 & 17 & 3.44 & 9 \\
\hline (f) Marketing Information & 1 & 10 & 27 & 42 & 20 & 3.69 & 6 \\
\hline (g) Safety/Accident Record & 7 & 16 & 33 & 25 & 19 & 3.32 & 13 \\
\hline (h) Staff Training Information & 2 & 6 & 22 & 40 & 30 & 3.93 & 5 \\
\hline (i) Company Ownership Information & 5 & 16 & 36 & 30 & 13 & 3.30 & 14 \\
\hline (j) News and Interviews with Staff & 4 & 16 & 37 & 27 & 16 & 3.36 & 11 \\
\hline (k) New Products \& Development & 1 & 3 & 12 & 46 & 38 & 4.20 & 2 \\
\hline (1) Fringe Benefits for Employees & 0 & 5 & 24 & 38 & 33 & 3.98 & 4 \\
\hline (m) Pension Information & 4 & 10 & 29 & 34 & 23 & 3.62 & 7 \\
\hline Future Staff Recruitment Prospects & 2 & 6 & 14 & 37 & 41 & 4.10 & 3 \\
\hline (o) Community Relations & 4 & 17 & 38 & 30 & 11 & 3.26 & 15 \\
\hline (p) Capital Expenditures & 5 & 21 & 40 & 26 & 8 & 3.10 & 16 \\
\hline (q) Future Plans of Company & 1 & 2 & 12 & 35 & 50 & 4.32 & 1 \\
\hline
\end{tabular}

\section{Employee views on disclosure and content of employee reports}

The amount of information given in employee reports varies considerably between companies (see Craig and Hussey (1982) for Australian evidence, and Firth and Smith (1984) for New Zealand evidence). It is of interest, therefore, to ascertain the views of employees as to the amount of information contained in the reports of their organisations (all 3 enterprises had about the median amount of disclosure when compared to all firms issuing reports).

A majority of respondents (61 percent) felt the employee reports had sufficient information, while a nother 30 percent felt there was not sufficient information and 9 percent felt there was too much information. There were no significant differences between replies given for each of the 3 companies, nor between the 5 age groups of the respondents. Among job classes, the only significant difference was for managerial staff who were more satisfied with existing levels of disclosure in the employee report. This response may reflect traditional management concerns about keeping information confidential to protect the company's position in labour negotiations and to keep sensitive information out of competitors' hands.

Employees were asked how important they perceived the information provided, as far as their own job was concerned. About half of the respondents ( 49 percent) thought the information provided was of little importance, while 33 percent saw the information provided as quite important. When the results were analysed according to job type and age group it was found that older employees (those over 40 years), plus managerial and administrative staff, were more likely to find the information provided important than were younger, unskilled and skilled employees.

To obtain an idea of what type of information employees would find relevant or important in an employee report, respondents were asked to rank a list of 17 categories of information according to a 5 point ordinal scale. A weighted average was obtained for each category of information. Table 1 shows the results obtained from this question.

A striking feature of employee responses was the high importance they attached to information which was future-oriented. In an era of great job uncertainty, employees are especially concerned with work security and this largely explains their preference for information on future prospects. For example, one employee commented:

The report relates to historical data which show what has been achieved and by whom. In contrast, the Board must make important financial decisions during the year which will

The scale is as follows: $1=$ not important, $2=$ slightly important, $3=$ moderately important. $4=$ highly important, $5=$ extremely important. 
manifest themselves $2-5$ years hence ... therefore it should be communicated to employees where it is reasonable to do so.

Another said:

Included in the report should be an HONEST plan of proposed company development discussing MEANINGFULLY the effects changes are going to have on staffing and the work environment.

The high rankings for new product development and marketing strategies are also interesting, and suggest that staff are curious to learn formally about new products before they are introduced. It may also reflect some concern about the competitiveness of the company vis-avis the offerings of other competitors in the market.

The above results should be of major importance to firms for, as Firth and Smith (1984) point out, very few of them publish such information in their current reports.

In contrast, financial-type information received relatively low ranking by employees, such as those recorded for summary profit and loss accounts, balance sheets, funds and added value statements. This is partly due to the highly aggregated nature of information (discussed later) and to the historical perspective of the data. This response should also be of concern to companies as historical financial accounting information forms the dominant content of many reports.

It was interesting to observe that safety and accident information received a low ranking. Perhaps this reflects a view that historical data is of little use or relevance to employees and that safety issues are likely to be closely monitored by trade unions. Employees are also likely to see direct evidence of safety and accident policies in the workplace. The moderate ranking associated with pensions is probably due to this type of information being also disseminated by other means (and in more detail). The same reasoning may well apply to safety and accident information, i.e. the employee report may add little or no incremental information to that provided by other sources.

The data presented in Table 1 were also broadly representative of the responses when broken down by company, age, and job type. Where there were differences in responses between the age groups, it was the very young (16-20) and to a lesser extent the young (21-30) age groups who placed a lower score on the information categories. This may indicate that younger workers have a short-term outlook for their employment, and information regarding the longerterm prospects of their job and firm is of little relevance.

In the few instances where there were significant differences in responses based on job categories, it was the administrative and unskilled employees who had the higher scores. The low ranking by managerial employees may reflect the fact that some of the information is already available to them in their workplace.

\section{Company-wide and division-wide information}

A typical feature of most employee reports is that the financial information provided is highly aggregated (Hilton, 1978; Firth and Smith. 1984).

In order to ascertain employees' opinions of the usefulness of such aggregation, they were asked whether they thought it was important that employee reports contain information on a divisional or plant-by-plant basis. The responses showed that employees had a strong preference for disaggregated information, with 43 percent believing it was very important. 47 percent moderately important, and 10 percent unimportant. These results suggest employees can have problems identifying with a report covering widely diverse activities of a large company and would prefer information about how their particular section of the company is doing. This is an important point as companies rarely close down completely, but are increasingly likely to close down a loss-making division or factory. Such disaggregated information would enable employees to assess more easily their job security. Typical of the views expressed on this point were:

With a highly diversified company, information relating to that part of the operation you are personally involved in is not easily obtained. Most information forthcoming is on matters over which you have no control or influence, therefore they hold little importance. 
and

A lot of the information in the report is of little interest as it does not refer to our particular centre. I would like to see separate information for each centre.

Again these responses have policy implications for companies. Very few employee reports contain disaggregated information, even though there is a strong demand for it.

\section{Conclusion}

Employee reports have become a major method of communicating corporate goals and information to employees in New Zealand enterprises.

This survey has found that employees welcome such reports and believe them to be an important source of information. The survey has also highlighted, however, that the disclosure and content of reports could be substantially improved. In particular, there is a clear signal that employees want more non-quantitative future-oriented information. There is also overwhelming evidence that employees would like to see disaggregated information rather than information about the company as a whole. Clearly employees have some difficulty in identifying with aggregated information of a large diversified company. They want direct information on how their section or division is performing. The message from our survey clearly shows that if employee reports are to continue to be favourably regarded by employees, then companies will need to pay greater attention to reorienting the content of the reports to meet more closely information requirements of its staff.

\section{References}

Craig, R and Hussey, R (1982) Keeping employees informed Butterworths, Sydney.

Firth, M A and Smith, A M C (1984) Reporting to employees New Zealand Society of Accountants, Costs \& Management Division, Bulletin No 26.

Hilton, A (1978) Employee reports - how to communicate financial information to employees Woodhead-Faulkner, Cambridge. 